\title{
Pengaruh DER, CAR, dan ROE terhadap Peringkat Obligasi Perbankan yang Listing di PT Bursa Efek Indonesia pada Periode 2008-2013
}

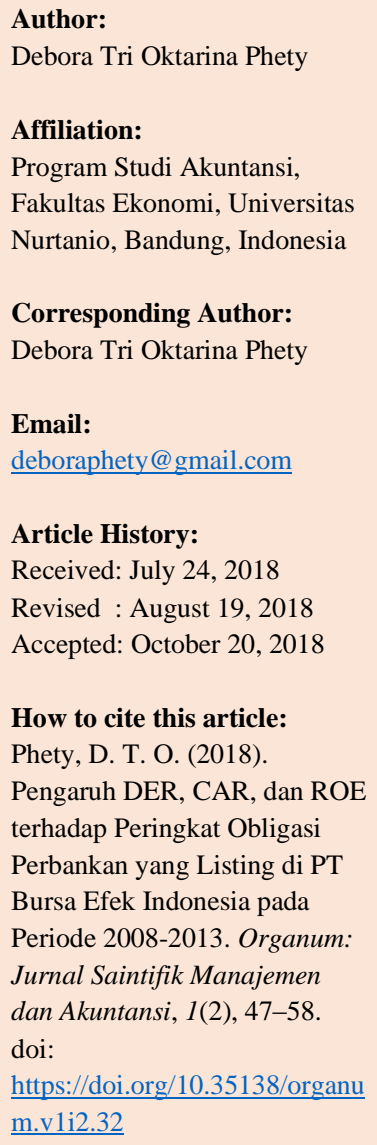

How to cite this article: Phety, D. T. O. (2018). Pengaruh DER, CAR, dan ROE terhadap Peringkat Obligasi Perbankan yang Listing di PT Bursa Efek Indonesia pada Periode 2008-2013. Organum: Jurnal Saintifik Manajemen dan Akuntansi, 1(2), 47-58. doi:

https://doi.org/10.35138/organu $\underline{\text { m.v1i2.32 }}$

Journal Homepage: ejournal.winayamukti.ac.id/ind ex.php/Organum

\section{Copyright:}

(c) 2018. Published by Organum: Jurnal Saintifik Manajemen dan Akuntansi. Faculty of Economics and Business. Winaya Mukti University.
Abstract. This study aims to analyze the effect of Debt to Equity Ratio (DER), Capital Adequacy Ratio (CAR) and Return on Equity (ROE) both partially and simultaneously to bank bond ratings. Bond rating agencies are needed to assess the performance of banks that issue bonds by providing information about the quality and risk of bonds. The phenomenon in Indonesia occured when several issuers failed to pay but had a bond rating at the investment grade level. The risk of a default on bonds was seen in the case of a failure to pay PT Bank Global Tbk bonds where the Kasnic rating agent gave an A-rating, but when BI announced a freeze on Bank Global's license, the bond rating was reduced to $D$. This research used Ordered Logit Model (OLM) as a method of data analysis. The random sampling method was carried out as a sampling method. The results of this study showed two things. First, the Capital Adequacy Ratio (CAR) and Return on Equity (ROE) had a positive impact on the bond rating. Second, the Debt to Equity Ratio (DER) had a negative impact on the bond rating. Whilst simultaneously Debt to Equity Ratio (DER), Capital Adequacy Ratio (CAR), and Return on Equity (ROE) affected the bond rating.

Keywords: Debt to Equity Ratio; Capital Adequacy Ratio; Return on Equity; bond rating.

Abstrak. Penelitian ini bertujuan untuk menganalisis pengaruh Debt to Equity Ratio (DER), Capital Adequacy Ratio (CAR) dan Return on Equity (ROE) baik secara parsial maupun simultan terhadap peringkat obligasi perbankan. Lembaga pemeringkat obligasi sangat diperlukan untuk menilai kinerja bank yang menerbitkan obligasi dengan memberikan informasi mengenai kualitas dan risiko obligasi. Fenomena di Indonesia terjadi saat beberapa emiten mengalami gagal bayar namun memiliki nilai peringkat obligasi yang berada di tingkat investment grade. Adanya risiko obligasi gagal bayar terlihat pada kasus gagal bayar obligasi PT Bank Global Tbk dimana agen pemeringkat Kasnic memberikan peringkat A-, tetapi pada saat BI mengumumkan pembekuan izin Bank Global, peringkat obligasi kemudian diturunkan menjadi D. Penelitian ini menggunakan Ordered Logit Model (OLM) sebagai metode analisis data. Metode random sampling dilakukan sebagai metode pengambilan sampling dalam riset ini. Hasil penelitian ini menunjukkan dua hal. Pertama, Capital Adequacy Ratio (CAR) dan Return on Equity (ROE) memiliki dampak positif terhadap rating obligasi. Terakhir, Debt to Equity Ratio (DER) memiliki dampak negatif terhadap rating obligasi. Sedangkan secara simultan Debt to Equity Ratio (DER), Capital Adequacy Ratio (CAR), dan Return on Equity (ROE) berpengaruh terhadap peringkat obligasi.

Kata kunci: Debt to Equity Ratio; Capital Adequacy Ratio; Return on Equity; rating obligasi. 


\section{Pendahuluan}

$\mathrm{P}$ erbankan merupakan penggerak roda perekonomian bagi suatu negara dan dilandaskan atas asas kepercayaan, asas kehati-hatian, dan asas kerahasiaan dari masyarakat. Menurut UU RI No 10 Tahun 1998 kegiatan utama Bank yaitu menghimpun dana dari masyarakat (funding), menyalurkan dana kepada masyarakat yang membutuhkan dana dalam bentuk kredit (lending), dan pelayanan (service). Sumber pendanaan perbankan menurut Kasmir (2008:65) berasal dari tiga pihak yaitu dana pihak kesatu, dana pihak kedua, dan dana pihak ketiga. Dana pihak kesatu merupakan dana yang bersumber dari bank itu sendiri yang merupakan setoran modal dari para pemegang saham. Dana pihak kedua merupakan sumber pendanaan yang berasal dari pinjaman lembaga lain. Dana pihak kedua ini bisa berasal dari pasar uang antar bank dan pasar modal. Sedangkan dana pihak ketiga yaitu dana yang berasal dari masyarakat. Perbankan wajib mencari sumber pendanaan lain dari pihak kedua yang dapat digunakan untuk pembiayaan kredit jangka panjang serta pencadangannya, yaitu dengan cara menerbitkan obligasi (Ikatan Bankir Indonesia, 2013:158).

Untuk mempermudah investor
awam
mengkualifikasikan risiko gagal bayar pada suatu perusahaan, maka dibuatlah rating atau peringkat. Perubahan rating pun dapat menentukan perubahan harga obligasi yang akan memengaruhi pendanaan perusahaan (Hadian, 2009:51). Adanya risiko obligasi gagal bayar terlihat pada kasus gagal bayar obligasi PT Bank Global Tbk. Untuk kasus PT Bank Global, agen pemeringkat Kasnic memberikan peringkat A-, tetapi pada saat BI mengumumkan pembekuan izin Bank Global, peringkat obligasi kemudian diturunkan menjadi D. Selain itu juga ada beberapa emiten yang diketahui mengalami gagal bayar, antara lain PT
Mobile-8 Telecom Tbk yang mengalami dua kali kegagalan pembayaran kupon yaitu 15 Maret 2009 dan 15 Juni 2009. Kemudian Davomas International Finance Company Pte.Ltd gagal membayar kupon obligasi periode 8 Mei 2009. Hal ini menunjukkan bahwa penilaian agen pemeringkat sangat dibutuhkan tetapi juga harus diawasi dalam pelaksanaan penilaiannya.

PT Pefindo merupakan salah satu lembaga pemeringkat obligasi di Indonesia. Informasi yang dikeluarkan oleh PT Pefindo akan direspon oleh investor dengan cara mengalokasikan dananya ke lembaga keuangan tersebut karena lembaga tersebut dianggap mampu untuk meningkatkan kesejahteraannya. Metode pemeringkatan Pefindo untuk lembaga keuangan didasarkan pada penilaian kebijakan manajemen perusahaan dan empat indikator keuangan, termasuk profitabilitas, struktur permodalan, perlindungan arus kas, dan fleksibilitas keuangan. Perusahaan yang memiliki peringkat obligasi yang rendah dan berada pada peringkat $\mathrm{B}$, akan kesulitan untuk menjual obligasi. Hal ini dikarenakan pangsa pasar akan berpindah pada perusahaan yang memiliki peringkat lebih baik atau lebih tinggi (Brigham, 2003:375).

Menurut Kasmir (2012:154) Debt to Equity Ratio (DER) menunjukkan tingkat perbandingan antara ekuitas dan hutang. Sugiyono (2009:71), menyatakan bahwa Debt to Equity Ratio menunjukkan perbandingan hutang dan modal dan berkaitan dengan masalah trading on equity yang dapat memberikan pengaruh positif dan negatif terhadap rentabilitas modal sendiri dan perusahaan tersebut. Capital Adequacy Ratio (CAR) mencerminkan kemampuan suatu bank untuk menutup risiko kerugian dari aktivitas yang dilakukannya dan kemampuan bank dalam mendanai kegiatan operasionalnya (Idroes, 2008:69). Kasmir (2014:46) menyatakan $C A R$ adalah perbandingan rasio antara 
rasio modal terhadap aktiva tertimbang menurut resikodan sesuai dengan ketentuan pemerintah. ROE merupakan ukuran profitabilitas perbankan yang digunakan untuk mengukur pengembalian bagi para pemegang saham (Jones et al, 2009:154). Menurut Hanafi (2007) rasio ini mengukur kemampuan perusahaan menghasilkan keuntungan pada tingkat penjualan, aset dan modal saham tertentu.

Tabel 1. Rata-Rata Rasio DER, CAR, ROE pada Bank BUMN, Bank Swasta Nasional, dan Bank Pembangunan Daerah Periode 2008-2013

Tahun

\begin{tabular}{lllllll}
\hline Rasio $(\%)$ & $\mathbf{2 0 0 8}$ & $\mathbf{2 0 0 9}$ & $\mathbf{2 0 1 0}$ & $\mathbf{2 0 1 1}$ & $\mathbf{2 0 1 2}$ & $\mathbf{2 0 1 3}$ \\
\hline DER & 9,50 & 9,69 & 7,22 & 10,17 & 8,66 & 8,05 \\
\hline CAR & 17,65 & 21,42 & 19,59 & 16,68 & 16,26 & 15,89 \\
\hline ROE & 20,46 & 15,25 & 19,92 & 20,03 & 20,35 & 19,17 \\
\hline
\end{tabular}

Sumber: Direktori Perbankan Indonesia diolah

DER antara tahun 2008 sampai tahun 2013 mengalami peningkatan dan penurunan secara fluktuatif. DER tertinggi terjadi pada tahun 2011 yaitu 10,17\%. Untuk $C A R$ antara tahun 2008 sampai dengan tahun 2013 juga mengalami peningkatan dan penurunan yang signifikan. CAR tertinggi terjadi pada tahun 2009 yaitu sebesar 21,41\%. Sedangkan pencapaian $R O E$ tertinggi antara tahun 2008 sampai tahun 2013 terjadi pada tahun 2012 sebesar 20,35\%. Dengan mengetahui kondisi rasio diatas diharapkan masyarakat memiliki alat bantu untuk dapat menilai kesesuaian peringkat obligasi dengan kinerja bank tersebut.

\section{Kajian Literatur}

Hasil penelitian terdahulu perlu dikaji kembali mengenai keterkaitan antar variabel penelitian. Hasil penelitian yang telah dilakukan Dwi Tyas Cahyo Wahono (2018) pada perusahaan manufaktur di Indonesia menyatakan bahwa Debt to Equity ratio, current ratio dan Return on Equity secara signifikan memengaruhi peringkat obligasi. Hal ini dipahami bahwa rasio keuangan yang menggambarkan kinerja keuangan memberikan kontribusi yang sangat besar dalam penetapan peringkat obligasi perusahaan tersebut. Sedangkan dalam penelitian Arvian Pandutama (2012) pada perusahaan manufaktur yang terdaftar di BEI menyatakan bahwa leverage, ukuran perusahaan, profitabilitas, pertumbuhan, jatuh tempo dan reputasi auditor tidak mempengaruhi peringkat obligasi secara signifikan.

Penelitian yang dilakukan oleh Hilda Indria Septyawati (2013) membuktikan bahwa leverage dan profitability berpengaruh terhadap peringkat obligasi. Bukti tersebut dapat dipahami bahwa penilaian terhadap suatu obligasi sangat dipengaruhi terutama rasio hutang dan rasio profitabilitas dimana rasio tersebut menunjukkan perusahaan memiliki kemampuan untuk melunasi hutang serta untuk menghasilkan keuntungan perusahaan. Sedangkan penelitian yang dilakukan oleh Nelly Thamida dan Hendro Lukman (2013) menyatakan bahwa profitabilitas dan likuiditas tidak signifikan memengaruhi peringkat obligasi perbankan yang terdaftar di BEI, dimana penetapan peringkat obligasi tidak dipengaruhi kemampuan perbankan dalam menghasilkan keuntungan maupun kemampuan untuk melunasi kewajiban jangka pendeknya. 
Dari hasil penelitian terdahulu dapat ditarik kesimpulan bahwa DER, CAR, dan ROE berpengaruh terhadap peringkat obligasi perbankan. Pengaruh tersebut bergantung kepada obyek penelitian masing-masing, ada yang berpengaruh positif maupun negatif dan juga berpengaruh kuat maupun lemah.

Menurut Ong, 2002 peringkat obligasi adalah opini mengenai kelayakan kredit dari penerbit obligasi yang didasarkan pada faktor-faktor risiko yang relevan. Peringkat obligasi digunakan untuk mengukur adanya risiko default atau gagal bayar dari perusahaan penerbit obligasi baik. Jewel dan Livingston (2000:6) menyimpulkan bahwa adanya informasi yang berbeda akan dapat menimbulkan berbagai macam karakteristik emiten.

Menurut Rahardjo, 2004 manfaat adanya peringkat obligasi bagi investor antara lain:

1. Informasi risiko investasi.

2. Rekomendasi Investasi.

3. Perbandingan.

Obligasi dapat dikategorikan menjadi investment grade dan noninvestment grade. Investment grade merupakan suatu kategori bahwa perusahaan dinggap memiliki kemampuan yang cukup untuk melunasi semua hutangnya. Sedangkan non-investment grade merupakan suatu kategori dimana perusahaan diragukan dalam memenuhi kewajibannya.

Tabel 2. Kategori Investment dan Non-Investment Grade

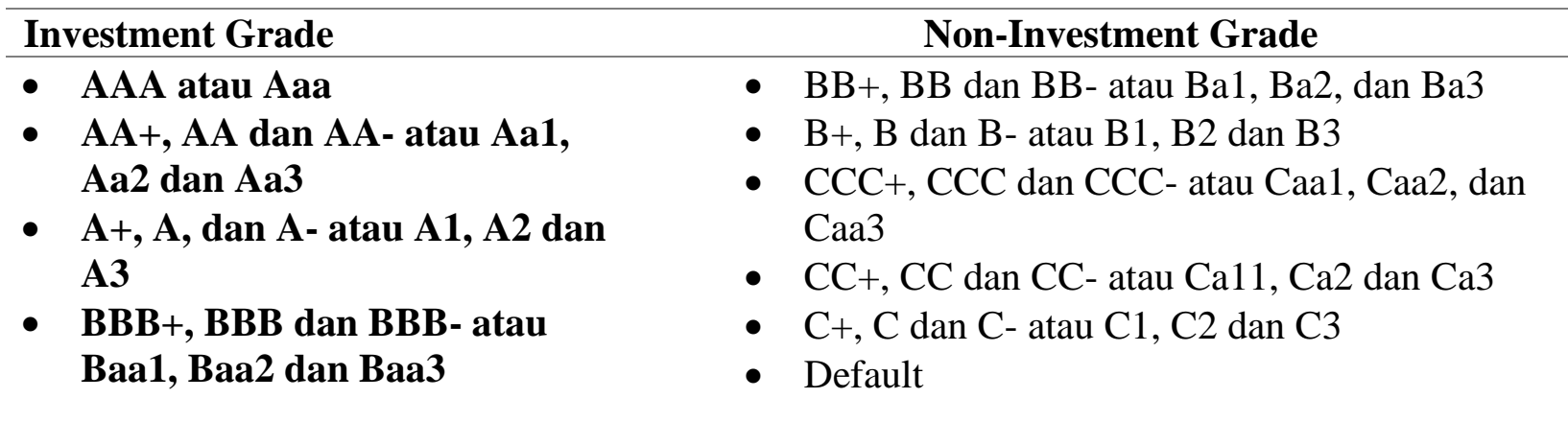

\section{Metode Penelitian}

Metode penelitian yang digunakan adalah metode penelitian kuantitatif, dan disajikan dengan time series, dengan pengolahan data menggunakan Ordered Logit Model (OLM). Penulis menggunakan $O L M$ karena variabel dependen dalam model ini merupakan variabel diskret yang bertingkat yang diubah menjadi skala ordinal sedangkan variabel independen menggunakan skala rasio. Sedangkan untuk variabel independen menggunakan skala rasio. Sumber data yang digunakan adalah data sekunder. Data yang digunakan dalam penelitian ini adalah Laporan Keuangan perbankan periode 2008-2013 sebanyak 23 sampel serta peringkat obligasi perbankan yang listing di Bursa Efek Indonesia yang tercatat pada website pefindo (www.pefindo.com). Teknik analisa data dalam penelitian ini menggunakan uji normalitas, uji multikolinearitas, uji heteroskedastisitas, uji linearitas, penilaian kesesuaian model, dan hasil estimasi model regresi logit.

Pengolahan data dalam penelitian ini dilakukan menggunakan SPSS 20 dan Eviews 6 untuk mengolah data serta memperoleh hasil dari variabel yang diteliti, yang terdiri dari variabel bebas (independent variable); Debt to Equity Ratio (DER), Capital Adequacy Ratio (CAR) dan Return on Equity (ROE), sedangkan variabel terikat (dependent variable); peringkat obligasi. 
Metode yang digunakan yaitu metode kuantitatif yang akan mengolah data sekunder yaitu laporan keuangan yang memuat Debt to Equity Ratio (DER), Capital Adequacy Ratio (CAR) dan Return on Equity (ROE). Data tersebut kemudian akan dianalisis dan diolah apakah terdapat pengaruh antara ketiga variabel diatas terhadap peringkat obligasi. Selain menggunakan metode statistik, penulis juga membandingkan hasil penelitianpenelitian sebelumnya sehingga akan dihasilkan keakuratan data dan pengambilan kesimpulan yang tepat dalam hasil penelitian ini.

Peneliti menggunakan beberapa referensi dalam menganalisis data dalam penelitian ini. Menurut Yamin (2009:119) regresi Ordered Logit Model (OLM) digunakan karena variabel dependennya merupakan suatu urutan (ordered), sehingga tidak dapat menggunakan model probabilitas linear seperti multinominal logit. Uji multikolinearitas menurut Imam Ghozali (2011:105) bertujuan untuk menguji apakah dalam model regresi tersebut ditemukan adanya korelasi antar variabel independen. Model regresi yang baik seharusnya tidak ditemukan adanya multikolinearitas. Menurut Ghozali (2011: 340) Likelihood $L$ dari model adalah probabilitas bahwa model yang dihipotesakan menggambarkan data input. Kriteria penolakan $\mathrm{H}_{0}$ dilakukan dengan melihat nilai probabilitas, dimana penolakan $\mathrm{H}_{0}$ dilakukan ketika probabilitas memiliki nilai yang lebih kecil dari $\alpha$. Sedangkan kriteria penerimaan $\mathrm{H}_{0}$ dilakukan ketika probabilitas memiliki nilai lebih besar dari $\alpha$.

Dalam regresi menggunakan metode logit, uji signifikansi parsial dilakukan dengan pendekatan normal sehingga kriteria pengujian menggunakan nilai $\mathrm{z}$. Apabila nilai z-stat lebih kecil dari nilai kritis maka $\mathrm{H}_{0}$ ditolak atau dengan kata lain variabel independen tersebut memengaruhi variabel dependen secara signifikan. Demikian pula sebaliknya, jika Z-Stat lebih besar dari nilai kritis maka $\mathrm{H}_{0}$ diterima. Menurut Ghozali (2011:341) Cox and Snell $R$ Square merupakan ukuran yang mencoba meniru ukuran $\mathrm{R}$ Square pada multiple regression yang didasarkan pada teknik estimasi likelihood dengan nilai maksimum kurang dari 1 (satu) sehingga sulit diinterpretasikan. Nagelkerke $R$ Square merupakan hasil modifikasi dari koefisien Cox and Snell $R$ Square untuk memastikan bahwa nilainya bervariasi dari 0 (nol) sampai dengan 1 (satu). Hasil dari nilai Nagelkerke $R$ Square menunjukkan persentase variabilitas variabel dependen yang dapat dijelaskan oleh variabel independen. Semakin tinggi nilai R-Square akan menunjukkan bahwa model semakin mampu memjelaskan variabel dependen.

Ghozali (2013:357) menyatakan model matematis dalam penelitian ini :

$$
\operatorname{Logit} \mathrm{P}(\mathrm{A})=\log \frac{\mathrm{P}(\mathrm{A})}{1-P(A)}
$$

Sehingga persamaannya menjadi :

$$
\begin{gathered}
\operatorname{Logit} \mathrm{P}(\mathrm{A})=\log \frac{\mathrm{P}(\mathrm{A})}{1-P(A)}=\alpha \mathrm{i} 0+\beta 1 \mathrm{DER} \\
+\beta 2 \mathrm{CAR}+\beta 3 \mathrm{ROE}+\mathrm{e}
\end{gathered}
$$

Kriteria penerimaan atau penolakan hipotesis berdasarkan pada signifikasi $p$ value pada kriteria jika nilai signifikansi< 0.05 maka Ha diterima. Sebaliknya jika nilai signifikansi> 0.05 maka Ha ditolak.

\section{Hasil dan Pembahasan}

Data yang dianalisis adalah data laporan keuangan perbankan dan peringkat obligasi perbankan selama periode 2008-2013. Data dapat dilihat di Tabel 1.

1. Debt to Equity Ratio (X1)

Dari data yang telah dikumpulkan diketahui bahwa dari 23 sampel perbankan yang listing di Bursa Efek Indonesia pada periode tahun 2008 hingga 2013 terjadi 
kenaikan komponen Debt to Equity Ratio (DER) yang berfluktuatif. Ratarata DER tertinggi terjadi pada tahun 2011 yaitu sebesar 10,17. DER tertinggi pada tahun 2011 dimiliki oleh Bank Himpunan Saudara 1906. Sedangkan rata-rata DER terendah terjadi pada tahun 2013 yaitu sebesar 8,05 . Tingkat DER terendah dimiliki oleh Bank Muamalat Indonesia.

2. Capital Adequacy Ratio (X2)

Pada tahun 2008 dan 2009 CAR mengalami kenaikan, kemudian terus menurun hingga tahun 2013. Rata-rata CAR tertinggi terjadi pada tahun 2009 sebesar 21,42. Pada tahun 2009 perbankan yang memiliki tingkat kecukupan modal tertinggi yaitu Bank
Ekspor Indonesia sebesar 40,76. Sedangkan rata-rata DER terendah dimiliki oleh Bank Permata sebesar 12,7 .

3. Return on Equity (X3)

Komponen Return on Equity (ROE) memiliki pola peningkatan yang hampir serupa dengan CAR dan DER. Rata-rata ROE tertinggi terjadi pada tahun 2008 sebesar 20,46. Tingkat ROE tertinggi dicapai oleh BPD Lampung sebesar 34,72, sedangkan tingkat ROE terendah dimiliki oleh Bank OCBC NISP Tbk.

Dibawah ini merupakan hasil deskriptif data dengan menggunakan SPSS 20.

Tabel 3. Descriptive Statistics

\begin{tabular}{|l|r|r|r|r|r|}
\hline \multicolumn{1}{|c|}{ Variable } & $\mathrm{N}$ & $\begin{array}{c}\text { Minimu } \\
\mathrm{m}\end{array}$ & $\begin{array}{c}\text { Maximu } \\
\mathrm{m}\end{array}$ & \multicolumn{1}{c|}{ Mean } & \multicolumn{1}{c|}{$\begin{array}{c}\text { Std. } \\
\text { Deviation }\end{array}$} \\
\hline DER & 254 & 1,86 & 25,87 & 8,9277 & 4,10570 \\
CAR & 254 & 10,59 & 40,76 & 17,0980 & 5,51563 \\
ROE & 254 &, 62 & 70,11 & 19,6939 & 10,31611 \\
Valid N & 254 & & & & \\
(listwise) & & & & & \\
\hline
\end{tabular}

Sumber: Hasil Pengolahan SPSS

Berdasarkan hasil output SPSS 20 diatas menunjukkan dari 254 data sampel pada periode 2008-2013, terlihat bahwa Debt to Equity Ratio (DER) memiliki nilai rata-rata 8,9277. Nilai minimum sebesar 1,86 dimiliki oleh Bank Exim pada tahun 2009. Nilai maksimum sebesar 25,87 dimiliki oleh Bank Pembangunan Daerah Sulawesi Utara pada tahun 2010. Besarnya standar deviasi adalah 4,10570.

Capital Adequacy Ratio (CAR) memiliki nilai rata-rata 17,0980 . Nilai CAR minimum sebesar $10,59 \%$ dimiliki oleh Bank ICB Bumiputera pada tahun
2013. Nilai $C A R$ maksimum sebesar 40,76\% yang dimiliki oleh Bank Exim pada tahun 2009. Besarnya standar deviasi sebesar 5,5163 menunjukkan indikasi terjadinya penyimpangan.

Return on Equity (ROE) memiliki nilai rata-rata 19,6939. $R O E$ maksimum sebesar 70,11 yang dimiliki oleh Bank Syariah Mandiri pada tahun 2013. ROE minimum sebesar 0,62 dimiliki oleh Bank ICB Bumiputera pada tahun 2013. Besarnya standar deviasi sebesar 10,31611 menunjukkan indikasi terjadinya penyimpangan. 


\section{Gambar 1. Hasil Uji Normalitas}

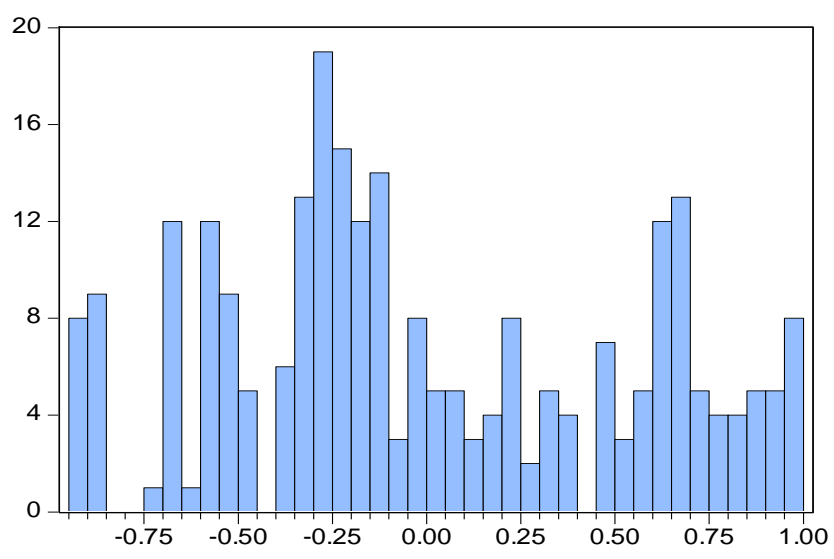

Series: Standardized Residuals Sample 163100143144161173 301

Observations 254

Mean $\quad 1.39 \mathrm{e}-09$

Median $\quad-0.105160$

Maximum 0.999228

Minimum $\quad-0.909521$

Std. Dev. $\quad 0.536431$

Skewness $\quad 0.219359$

Kurtosis $\quad 1.981513$

Jarque-Bera 13.01528

Probability $\quad 0.001492$

Sumber: Hasil Pengolahan Data Program Eviews 6.

Hasil output dari Eviews 6 menunjukkan bahwa variabel independen memiliki nilai JB sebesar 13,01528, lebih besar jika dibandingkan dengan tabel chi- square 2df signifikansi 0,10 sebesar 4,60517. Hal ini menunjukkan bahwa data tidak terdistribusi normal.

Tabel 4. Hasil Uji Multikolinieritas

\begin{tabular}{|c|c|c|}
\hline Independent & \multicolumn{2}{|c|}{ Collinearity Statistics } \\
\cline { 2 - 3 } Variable & Tolerance & VIF \\
\hline CAR &, 653 & 1,531 \\
DER &, 637 & 1,569 \\
ROE &, 122 & 8,169 \\
$\mathrm{ROE}^{\wedge} 2$ &, 132 & 7,575 \\
\hline
\end{tabular}

Sumber: Hasil Pengolahan Data Program IBM-SPSS 20

Uji multikolinearitas bertujuan untuk menguji apakah dalam model regresi tersebut ditemukan adanya korelasi antar variabel independen Jika nilai tolerance $>0,10$ maka tidak terjadi multikolinearitas. Jika dilihat pada tabel nilai VIF CAR, DER, ROE serta fungsi kuadrat pun dibawah 10,00. Hal ini membuktikan bahwa tidak terjadi multikolinearitas.
Adanya heteroskedastisitas data menyebabkan pengambilan keputusan statistik untuk pengujian hipotesis menjadi tidak valid (Ghozali,2013:95). Untuk menguji adanya heteroskedastisitas perlu dilakukan Uji Glejser. Dari hasil Uji Glejser dilihat pada Tabel 7 untuk variabel CAR dan DER memiliki nilai lebih kecil dari $\alpha 0,10$. Dengan demikian berarti $\mathrm{H}_{\mathrm{a}}$ diterima, dan terdapat heteroskedastisitas. 


\section{Tabel 5. Hasil Uji Heteroskedastistas dengan Uji Glesjer}

Dependent Variable: ABSRES

Method: Least Squares

Date: 04/18/16 Time: 18:28

Sample: 163100143144161173301

Included observations: 254

\begin{tabular}{crrrr}
\hline \hline Variable & Coefficient & Std. Error & t-Statistic & Prob. \\
\hline \hline C & 0.939536 & 0.112971 & 8.316632 & 0.0000 \\
CAR & -0.021635 & 0.003732 & -5.798035 & 0.0000 \\
DER & -0.010288 & 0.005074 & -2.027652 & 0.0437 \\
ROE & 0.000819 & 0.004608 & 0.177744 & 0.8591 \\
ROE$^{\wedge} 2$ & $-7.76 E-05$ & $8.22 \mathrm{E}-05$ & -0.944869 & 0.3456 \\
\hline \hline
\end{tabular}

Sumber: Hasil Pengolahan Data E-Views 6.

Linearitas merupakan suatu keadaan dimana hubungan antara variabel independen dan dependen bersifat linier, baik positif maupun negatif (Santoso,2009:192). Menurut Ghozali (2007:228) dalam model regresi logistik, hubungan antara probabilitas dengan variabel bebas tidak linier. Ghozali (2007:118) menyarankan untuk menggunakan uji Ramsey RESET untuk menguji terdapatnya ketidaklinieran hubungan tersebut.

Tabel 6. Hasil Uji Linieritas dengan Ramsey RESET

\begin{tabular}{llll}
\hline \hline F-statistic & 28.11259 & Prob. F (1,248) & 0.0000 \\
Log likelihood ratio & 27.27451 & Prob. Chi-Square (1) & 0.0000 \\
\hline \hline
\end{tabular}

Test Equation:

Dependent Variable: PCP_1

Method: Least Squares

Date: 04/18/16 Time: 18:59

Sample: 1254

Included observations: 254

\begin{tabular}{crrrr}
\hline \hline Variable & Coefficient & Std. Error & t-Statistic & Prob. \\
\hline \hline C & 1.406162 & 0.172378 & 8.157431 & 0.0000 \\
CAR & 0.125700 & 0.021091 & 5.959922 & 0.0000 \\
DER & -0.070973 & 0.011842 & -5.993172 & 0.0000 \\
ROE & 0.059947 & 0.010034 & 5.974391 & 0.0000 \\
ROE^2 & -0.000737 & 0.000127 & -5.799479 & 0.0000 \\
FITTED $^{\wedge} 2$ & -4.249485 & 0.801467 & -5.302131 & 0.0000 \\
\hline \hline
\end{tabular}

Prob dari nilai $\mathrm{F}$ sebesar 0,000 dan nilai tersebut lebih kecil dari $\alpha$. Dengan demikian maka $\mathrm{H}_{0}$ diterima atau $\mathrm{H}_{\mathrm{a}}$ ditolak.
Menurut Ghozali (2007:237-238) ada beberapa cara untuk menilai model fit. Salah satunya yaitu dengan melihat penurunan nilai -2LogLikelihood. 
Tabel 7. Model Fitting Information

\begin{tabular}{|l|r|r|r|r|}
\hline Model & \multicolumn{1}{|c|}{$\begin{array}{c}-2 \text { Log } \\
\text { Likelihood }\end{array}$} & Chi-Square & df & \multicolumn{1}{c|}{ Sig. } \\
\hline Intercept Only & 980,932 & & & \\
Final & 874,087 & 106,845 & & 4 \\
\hline
\end{tabular}

Link function: Logit.

Sumber: Hasil Pengolahan Data Program IBM-SPSS 20.

Pada Tabel 9 dapat dilihat bahwa model dengan intercept saja menghasilkan nilai $\quad-2$ LogLikelihood 980,932, sedangkan jika variabel independen dimasukkan ke dalam model, maka nilai 2 LogLikelihood turun menjadi 874,087 dan penurunan ini signifikan pada 0,00 . Jadi dapat disimpulkan bahwa model fit.
Uji simultan identik dengan uji kelayakan model. Hasil signifikansi sebesar $0,000<$ dari $\alpha$ sebesar $5 \%$ menunjukkan bahwa variabel $D E R, C A R$, dan $R O E$ secara simultan berpengaruh signifikan terhadap peringkat obligasi.

Tabel 8. Hasil Estimasi Model Ordered Logit: Pengaruh Kecukupan Modal, Leverage, Dan Profitabilitas Terhadap Peringkat Obligasi

\begin{tabular}{|c|c|c|c|c|c|c|}
\hline & & Estimate & $\begin{array}{l}\text { Std. } \\
\text { Error }\end{array}$ & Wald & df & Sig. \\
\hline \multirow[t]{9}{*}{ Threshold } & $\begin{array}{l}\text { [Rating = } \\
0]\end{array}$ & $-7,202$ & 1,117 & 41,572 & 1 & ,000 \\
\hline & $\begin{array}{l}{[\text { Rating }=} \\
1]\end{array}$ & $-5,679$ & ,930 & 37,274 & 1 & , 000 \\
\hline & $\begin{array}{l}\text { [Rating }= \\
2]\end{array}$ & $-4,074$ & ,866 & 22,151 & 1 & ,000 \\
\hline & $\begin{array}{l}{[\text { Rating }=} \\
3]\end{array}$ & $-3,429$ & ,853 & 16,167 & 1 & , 000 \\
\hline & $\begin{array}{l}{[\text { Rating }=} \\
4]\end{array}$ & $-2,882$ & 844 & 11,649 & 1 & ,001 \\
\hline & $\begin{array}{l}{[\text { Rating }=} \\
5]\end{array}$ & $-2,344$ & ,837 & 7,838 & 1 & ,005 \\
\hline & $\begin{array}{l}{[\text { Rating }=} \\
6]\end{array}$ & $-1,288$ & ,826 & 2,434 & 1 & , 119 \\
\hline & $\begin{array}{l}{[\text { Rating }=} \\
7]\end{array}$ &,- 951 & ,824 & 1,331 & 1 & ,249 \\
\hline & $\begin{array}{l}{[\text { Rating }=} \\
8]\end{array}$ &,- 155 & 825 & ,035 & 1 & ,851 \\
\hline \multirow[t]{4}{*}{ Location } & DER &,- 108 & ,035 & 9,543 & 1 & ,002 \\
\hline & CAR & ,099 & ,033 & 9,076 & 1 & ,003 \\
\hline & ROE &,- 186 & ,033 & 31,320 & 1 & ,000 \\
\hline & ROE2 &, 003 & ,001 & 19,019 & 1 & ,000 \\
\hline
\end{tabular}

\section{Link function: Logit.}

Persamaan regresinya adalah sebagai berikut:

Logit $(\mathrm{p} 0)=-7,202-0,108 \mathrm{X} 1+0,099 \mathrm{X} 2-0,186 \mathrm{X} 3+0,03 \mathrm{X} 4$ 
Logit $(\mathrm{p} 0+\mathrm{p} 1)=-5,679-0,108 \mathrm{X} 1+0,099 \mathrm{X} 2-0,186 \mathrm{X} 3+0,03 \mathrm{X} 4$

Logit $(\mathrm{p} 0+\mathrm{p} 1+\mathrm{p} 2)=-4,074-0,108 \mathrm{X} 1+0,099 \mathrm{X} 2-0,186 \mathrm{X} 3+0,03 \mathrm{X} 4$

Logit $(\mathrm{p} 0+\mathrm{p} 1+\mathrm{p} 2+\mathrm{p} 3)=-3,4239-0,108 \mathrm{X} 1+0,099 \mathrm{X} 2-0,186 \mathrm{X} 3+0,03 \mathrm{X} 4$

Logit $(\mathrm{p} 0+\mathrm{p} 1+\mathrm{p} 2+\mathrm{p} 3+\mathrm{p} 4)=-2,882-0,108 \mathrm{X} 1+0,099 \mathrm{X} 2-0,186 \mathrm{X} 3+0,03 \mathrm{X} 4$

Logit $(\mathrm{p} 0+\mathrm{p} 1+\mathrm{p} 2+\mathrm{p} 3+\mathrm{p} 4+\mathrm{p} 5)=-2,344-0,108 \mathrm{X} 1+0,099 \times 2-0,186 \mathrm{X} 3+0,03 \mathrm{X} 4$

Logit $(\mathrm{p} 0+\mathrm{p} 1+\mathrm{p} 2+\mathrm{p} 3+\mathrm{p} 4+\mathrm{p} 5+\mathrm{p} 6)=-1,288-0,108 \mathrm{X} 1+0,099 \mathrm{X} 2-0,186 \mathrm{X} 3+0,03 \mathrm{X} 4$

Logit $(\mathrm{p} 0+\mathrm{p} 1+\mathrm{p} 2+\mathrm{p} 3+\mathrm{p} 4+\mathrm{p} 5+\mathrm{p} 6+\mathrm{p} 7)=-0,951-0,108 \mathrm{X} 1+0,099 \mathrm{X} 2-0,186 \mathrm{X} 3+0,03 \mathrm{X} 4$

Logit $(\mathrm{p} 0+\mathrm{p} 1+\mathrm{p} 2+\mathrm{p} 3+\mathrm{p} 4+\mathrm{p} 5+\mathrm{p} 6+\mathrm{p} 7+\mathrm{p} 8)=-0,155-0,108 \mathrm{X} 1+0,099 \times 2-0,186 \mathrm{X} 3+$ $0,03 \mathrm{X} 4$

Berdasarkan hasil output fungsi
Logit menunjukkan bahwa nilai
probabilitas statistik Wald Debt to Equity Ratio sebesar 0,002 dan estimate $-0,108$. Karena nilai probabilitas lebih kecil dari $\alpha$ sebesar $5 \%$ maka $\mathrm{H}_{0}$ ditolak. Hal ini menunjukkan bahwa Debt to Equity Ratio (DER) secara parsial berpengaruh negatif terhadap peringkat obligasi perbankan. Ini berarti bahwa peningkatan DER akan menyebabkan penurunan peringkat obligasi perbankan. Hasil perhitungan hipotesis pertama dapat dibuktikan pada obligasi General Obligation dan Bond I Year 2003 yang diterbitkan oleh Bank Negara Indonesia Persero Tbk. DER pada tahun 2009 sebesar 10,88 menurun menjadi 10,01 di tahun 2010 menyebabkan kenaikan peringkat obligasi dari idAA- menjadi idAA.

Nilai probabilitas statistik Wald untuk Capital Adequacy Ratio sebesar 0,003 dan estimate 0,009 menunjukkan bahwa Capital Adequacy Ratio (CAR) secara parsial berpengaruh positif terhadap peringkat obligasi perbankan. Hal ini menyatakan bahwa peningkatan $C A R$ akan menyebabkan kenaikan peringkat obligasi. Hasil perhitungan hipotesis kedua dibuktikan pada kenaikan peringkat pada General Obligation yang diterbitkan oleh Bank Lampung pada tahun 2009 dari peringkat $\mathrm{BBB}+$ menjadi A-. Bank Lampung mengalami peningkatan CAR sebesar pada tahun 2009 yaitu sebesar 21,58 menjadi 28,40 pada tahun 2010.

Nilai probabilitas statistik Wald untuk Return on Equity (ROE) 0,000 dan estimate $-0,186$ menunjukkan bahwa
Return on Equity (ROE) secara parsial berpengaruh negatif terhadap peringkat obligasi perbankan. Hasil ini menyatakan bahwa kenaikan $R O E$ dapat menyebabkan peringkat obligasi menurun atau tetap. Hal ini dibuktikan pada General Obligation yang diterbitkan oleh Bank SULUT pada tahun 2009. Pada tahun 2009 Bank SULUT memiliki ROE sebesar 19,68 dan mengalami peningkatan yang signifikan di tahun 2010 menjadi 32,46. Tetapi hal tersebut membuat peringkat obligasi tersebut tetap di idA-.

Dari hasil uji simultan berdasarkan uji kelayakan model diatas, dapat diketahui bahwa variabel $D E R, C A R$, dan $R O E$ secara simultan berpengaruh signifikan terhadap peringkat obligasi. Hal ini sejalan dengan penelitian yang dilakukan oleh Dwi Tyas Cahyo Wahono (2018) dan Hilda Indria Septyawati (2013).

\section{Kesimpulan}

Dari hasil penelitian yang telah dilakukan menunjukkan bahwa terdapat pengaruh signifikan baik secara parsial maupun simultan antara Debt to Equity Ratio (DER), Capital Adequacy Ratio (CAR), dan Return on Equity (ROE) terhadap peringkat obligasi perbankan dan didukung oleh penelitian terdahulu serta bukti data-data hasil perhitungan statistik yang dibandingkan dengan perubahan data peringkat obligasi.

Untuk meningkatkan kepercayaan investor menanamkan investasi pada obligasi perbankan, maka perbankan harus tetap menjaga atau menurunkan 
Debt to Equity Ratio (DER), meningkatkan Capital Adequacy Ratio (CAR), dan meningkatkan Return on Equity (ROE) sehingga investor akan meningkatkan dana yang ditempatkan untuk investasi serta berpotensi untuk menambah dana pihak ketiga bank tersebut.

\section{Daftar Pustaka}

Brigham, E. F. \& Daves, P. R. (2003). Intermediate Financial Management with Thomson One. United States of America: Cengage South-Western.

Ghozali, I. (2007). Aplikasi Analisis Multivariate Dengan Program SPSS. Semarang: BP Universitas Diponegoro.

. (2011). Aplikasi Analisis Multivariate Dengan Program SPSS. Cetakan Keempat. Semarang: Badan Penerbit Universitas Diponegoro.

. (2013). Aplikasi Analisis Multivariate Dengan Program SPSS. Edisi Ketujuh. Semarang: Badan Penerbit Universitas Diponegoro.

Hadian, N. (2009). Pengaruh Perubahan Peringkat Obligasi, Tingkat Suku Bunga SBI, Pertumbuhan PDB, Kurs Rupiah-USD dan Inflasi terhadap Perubahan Harga Obligasi Korporasi Yang Listing di PT BEI. Tesis. Program Studi Magister Manajemen. Universitas Katolik Parahyangan.

Hanafi, M. M. \& Halim, A. (2007). Analisis Laporan Keuangan. Yogyakarta: UPPYKPN.

Idroes, F. N. (2008). Manajemen Risiko Perbankan. Jakarta: Rajawali Pers.

Ikatan Bankir Indonesia. (2013). Memahami Bisnis Bank. Jakarta: PT Gramedia Pustaka Utama.
Indonesia (1998). Undang-Undang Republik Indonesia No.10/1998 Tentang Perubahan Atas UndangUndang No.7 Tahun 1992 Tentang Perbankan. Jakarta: Presiden Republik Indonesia.

Jewell, J., \& Livingston, M. B. (2000). The Impact of a Third Credit Rating on the Pricing of Bond. The Journal of Fixed Income, 10(3), 69-85. doi: https://doi.org/10.3905/jfi.2000.319 275

Jones, J. P. et al. (2009). Cornerstones of Financial \& Managerial Accounting Current Trends and Update. Mason: South-Western Cengage Learning.

Kasmir, K. (2008). Bank dan Lembaga Keuangan Lainnya. Edisi Revisi 2008. Jakarta: PT Raja Grafindo Persada.

Kamir, K. (2012), Analisis Laporan Keuangan. Jakarta: PT Raja Grafindo Persada.

Kamir, K. (2014), Dasar-dasar Perbankan. Edisi Revisi 2008. Jakarta: PT Raja Grafindo Persada.

Ong, M. K. (2002). Credit Rating Methodologies, Rationale, and Default Risk. London: Risk Books.

Pandutama, A. (2012). Faktor-faktor Yang Mempengaruhi Peringkat Obligasi Pada Perusahaan Manufaktur di BEI. Jurnal Ilmiah Mahasiswa Akuntansi, 1(4), 82-87. Diakses dari http://journal.wima.ac.id/index.php/ JIMA/article/viewFile/252/247

Rahardjo, S. (2004). Panduan Investasi Obligasi. Jakarta: PT Gramedia Pustaka Utama.

Septyawanti, H. I. (2013). Faktor-faktor Yang Mempengaruhi Peringkat Obligasi Perusahaan. Accounting Analysis Journal, 2(3), 276-285. 
Diakses

dari https://journal.unnes.ac.id/sju/index. php/aaj/article/view/2506

Singgih, S. (2009). Panduan Lengkap Menguasai Statistik Dengan SPSS 17. Jakarta: PT Elex Media Komputindo.

Sugiyono, S. (2009). Metode Penelitian Kuantitatif, Kualitatif dan $R \& D$. Bandung: Alfabeta.

Thamida, N. \& Lukman, H. (2013). Analisis Faktor-faktor Yang Mempengaruhi Peringkat Obligasi Pada Industri Perbankan Yang Terdaftar di Bursa Efek Indonesia Periode 2008-2012. Jurnal Akuntansi, 27(2), 198-211. Diakses dari

http://portal.kopertis3.or.id/handle/1 $\underline{23456789 / 2013}$
Wahono, D. T. C., Sadikin, A. \& Widyarfendhi. (2018). Pengaruh Rasio Keuangan Terhadap Peringkat Obligasi Manufaktur Yang Terdaftar di Bursa Efek Indonesia Tahun 2010-2011. Jurnal Ilmiah Bisnis dan Keuangan, 8(1), 7-18. Diakses dari http://journal.stiei-kayutangibjm.ac.id/index.php/jibk/article/vie $\mathrm{w} / 379 / 194$

Yamin, S. \& Kurniawan, H. (2009). SPSS Complete Teknik Analisis Statistik Terlengkap dengan Software SPSS. Jakarta: Salemba Empat. 